\title{
PROTECTION

\section{THE NARRATIVE APPROACH TO LIVING HERITAGE}

\section{WALTER Nigel ${ }^{1}$}

${ }^{1}$ Nigel Walter, Department of Archaeology, University of York, The King's Manor, York YO1 7EP UK https://orcid.org/0000-0002-1152-522X

ABSTRACT: This paper attempts to sketch out a theoretical framework that addresses the particular needs of living heritage. ICCROM has been at the forefront of developing a conservation practice which addresses the concerns of living heritage such as religious and pilgrimage sites (e.g. Wijesuriya 2015; Wijesuriya, Thompson, and Court 2017), and others have considered the implications for the conservation process (e.g. Poulios 2014). However, to date there has been no attempt to develop a theoretical foundation for these practices. In place of the still-dominant understanding (at least as encountered in much Western practice) of historic buildings as primarily art-historical, this paper proposes a narrative approach that allows the site or building to remain within its cultural/religious context, including an acceptance of ongoing change. While the argument proceeds from Western sources, it invites dialogue with complementary understandings of the working of tradition from other regions of the world.

Any theoretical model for living heritage must address the central question of how living buildings endure between generations, that is, their continuity between past, present and future. Since modernity entails a commitment to a radical discontinuity with the past, such an approach must engage with the resources of premodernity to develop (or perhaps return to) a non-modern understanding of tradition as developmental and creative (Walter, 2017). The principal sources used in the investigation of this proposed narrative approach include Alasdair MacIntyre's rehabilitation of tradition, Hans-Georg Gadamer's development of philosophical hermeneutics and Paul Ricoeur's work on narrative and time.

KEY WORDS: Tradition, continuity, Alasdair MacIntyre, Hans-Georg Gadamer, Paul Ricoeur 


\section{Nigel Walter}

\section{Conservation, change and living heritage}

There is a profound irony at the heart of modern conservation, that while it is concerned with the well-being of the material production of 'traditional' cultures, it itself is the product of modernity. On the one hand conservation cares for the objects of tradition, but on the other hand a principal concern of modernity from the Enlightenment onwards has been the overcoming of tradition. This tension feeds into contemporary battles over how much change is permissible to historic buildings.

The desire for a new beginning, a bidding farewell to the past, are central aspects of modernity. Paul de Man characterizes it as

a desire to wipe out whatever came earlier, in the hope of reaching at last a point that would be called a true present, a point of origin that marks a new departure. This combined interplay of deliberate forgetting with an action that is also a new origin reaches the full power of the idea of modernity ${ }^{1}$.

With an underlying belief in progress, modernity becomes synonymous with change. The twentieth-century redevelopment of many cities, often following large-scale conflict, typically involved the further deliberate destruction of surviving historic buildings. Modern conservation, born in response to nineteenth-century restoration, developed as a form of resistance to that change. But the anthropologist Bruno Latour highlights another implication of modernity's belief in temporal discontinuity:

As Nietzsche observed long ago, the moderns suffer from the illness of historicism. They want to keep everything, date everything, because they think they have definitively broken with their past. The more they accumulate revolutions, the more they save; the more they capitalize, the more they put on display in museums. Maniacal destruction is counterbalanced by an equally maniacal conservation ${ }^{2}$.

Conservation is an essentially modern phenomenon, and from a community perspective can indeed appear 'maniacal' in its more preservationist forms.

Some forms of change are inevitable, and conservation is now often understood as the management of change. It was Sir Bernard Feilden who seems first to have defined conservation in this way, as 'the dynamic management of change in order to reduce the rate of decay'3; this was in the mid 1980s, at a conference on air pollution. Historic England - the government's statutory advisor on England's heritage - adapted this definition, expanding its scope to allow

1 de Man P., Literary history and literary modernity, Daedalus, 99(2), 1970, pp. 388-389.

2 Latour B.. We have never been modern (C. Porter, Trans.), Cambridge, MA: Harvard University Press, 1993, p. 69.

3 Cited in Lagerqvist, B., Holmberg I. M., Wetterberg O., Integrated Conservation of Built Environments: Swedish Reflections from Three Decades of Program Development, [in:] B. L. Stiefel, J. C. Wells (Eds.), Preservation education: Sharing best practices and finding common ground (pp. 114-130). University Press of New England, 2014, p. 119. 
that significance can be enhanced ${ }^{4}$. The Burra Charter also refers to change as something to be managed ${ }^{5}$, but otherwise advocates a cautious approach to change: do as much as necessary to care for the place and to make it useable, but otherwise change it as little as possible...' ${ }^{\prime}$. Change is often still equated with harm, and many conservation professionals see their role therefore being to resist change. Thus Michael Petzet treats conservation and the idea of managing change as standing in opposition to one another. In a paper entitled 'Conservation or Managing Change?' he suggested that

the core ideology of [ICOMOS] is being counteracted. After all, conservation does not mean "managing change" but preserving, - preserving, not altering and destroying: ICOMOS [...] is certainly not an International Council on Managing Change?

Petzet's paper was reprinted in the published proceedings of two meetings of the International Scientific Committee for Theory and Philosophy of Conservation and Restoration ${ }^{8}$, in which he opposed Gustavo Araoz's call for a 'new heritage paradigm", central to which is the notion of the historic environment's 'tolerance for change ${ }^{10}$.

The logic of defining conservation as the management of change suggests that as well as the possibility of too much change, there is at least some danger of allowing too little change. Change presents such difficulties for conservation in part because our current methodology has no means of evaluating either the desirability or quality of proposed change. Too often, change is equated with harm, and conservation processes become adept at erecting barriers to change, frustrating community ambition and leading to the progressive detachment of already fragile communities from their buildings. Conservation lacks an adequate account of how heritage is created, and therefore of how change can positively enhance an evolving and inclusivelyowned historic environment. Typically, the assumption is that there is a finite stock of heritage which has been inherited from an inaccessible past and which can only now decrease; as a result conservation rarely engages with contemporary cultural debate, except to defend the inherited past from change.

Living buildings - those that are still in use for the purposes for which they were built - throw the issue of change into sharp relief. In his study of the living monastic sites at Meteora in Greece, Ioannis Poulios helpfully addresses these issues. In his analysis, the material-based approach to

4 Historic England, Conservation principles: Policies and guidance for the sustainable management of the historic environment, London: English Heritage, 2008, pp. 71; 15, 46.

5 Australia ICOMOS, The Burra Charter: The Australia ICOMOS charter for places of cultural significance, Burwood, Australia: Australia ICOMOS, 2013, Art. 27, https://australia.icomos.org/wp-content/uploads/TheBurra-Charter-2013-Adopted-31.10.2013.pdf

6 Ibidem, Preamble.

7 Petzet M., International principles of preservation, Berlin: Hendrik Bäßler Verlag, 2009, p. 9.

8 Lipp W., Štulc J., Szmygin B., Giometti S. (Ed.), Conservation turn - return to conservation: Tolerance for change, limits of change, Firenze: Edizioni Polistampa, 2012.

9 Araoz G. F., Preserving heritage places under a new paradigm, Journal of Cultural Heritage Management and Sustainable Development, 1(1), 2011, p. 56, https://doi.org/DOI 10.1108/20441261111129933.

10 Araoz was Petzet's immediate successor as ICOMOS President. 
conservation has failed because it creates 'a form of discontinuity ... between the monuments and the people, and between the past and the present ${ }^{\prime 11}$; the current values-based approach, does nothing to challenge the assumptions of late modernity, such that 'the aim of conservation remains the preservation of heritage, considered to belong to the past, from the people of the present, for the sake of the future generations (discontinuity) ${ }^{\prime 2}$. By contrast, Poulios places what he terms the 'core community' at the centre of the process and proposes an alternative framework based on the key concept of continuity of living heritage; this he breaks down into the four criteria of continuity of function, continuity of the community's connection with the heritage site, continuity of care through communal management and ownership mechanisms, and continuity of change (within tradition) in the expression of heritage ${ }^{13}$.

\section{English parish churches}

My particular area of professional work is the conservation and change of medieval English parish churches; these offer a local example of the challenges of living buildings and the sometimes fraught relations between core communities and conservation professionals. There are some 17,600 Anglican church buildings in England, of which approximately half are substantially medieval. The Church of England maintains its medieval responsibility for the 'cure of souls' - that is, for the care of everyone - in each parish; in a meaningful sense each church building thus belongs to everyone in that community regardless of religious affiliation. Hence rural parish churches, which are typically medieval, have been described as 'truly democratic buildings, the meeting place of ordinary people through the ages ${ }^{14}$. Typically, of course, it is on the core community of those who choose to attend a given church that the burden of the building's upkeep falls. It was the early recognition of the living heritage status of church buildings that led to the development in England of the 'ecclesiastical exemption', a parallel regulatory system ${ }^{15}$.

Parish churches face increasing pressure for change, with projects varying in scope from major alteration schemes to modest proposals for the addition of toilets and kitchens, often combined with some reordering of the seating. While there is broad acceptance that it is important to keep these buildings in use, disagreements between church communities and heritage professionals regarding the extent of acceptable change can be substantial, with the latter often seeing the willingness of the former to countenance change as ignorant and cavalier. That it can be easier to obtain permission for adaptive re-use where the original faith community has died out than it is for the changes that enable that core community to survive and thrive demonstrates stark differences in the understanding of the living heritage link between buildings and people. It is

${ }_{11}$ Poulios I., The past in the present: A living heritage approach-Meteora, Greece. London: Ubiquity Press, 2014, p. 20.

12 Ibidem, p. 22.

13 Ibidem, pp. 115-119.

14 Strong R., A little history of the English country church, London: Jonathan Cape, 2007, p. 233.

15 Walter N., Narrative theory in conservation: Change and living buildings, Abingdon and New York: Routledge, 2020 , chapter 3 case study. 
in this nexus - in Latin, literally 'the binding together' - of building and community that the heritage we are tasked with conserving is found. The uncomfortable truth is that any process that conceives of heritage in narrowly architectural and historic terms - as legislative frameworks typically do in the West - easily sidelines the core community and becomes complicit in the destruction of the very heritage which it supposedly protects.

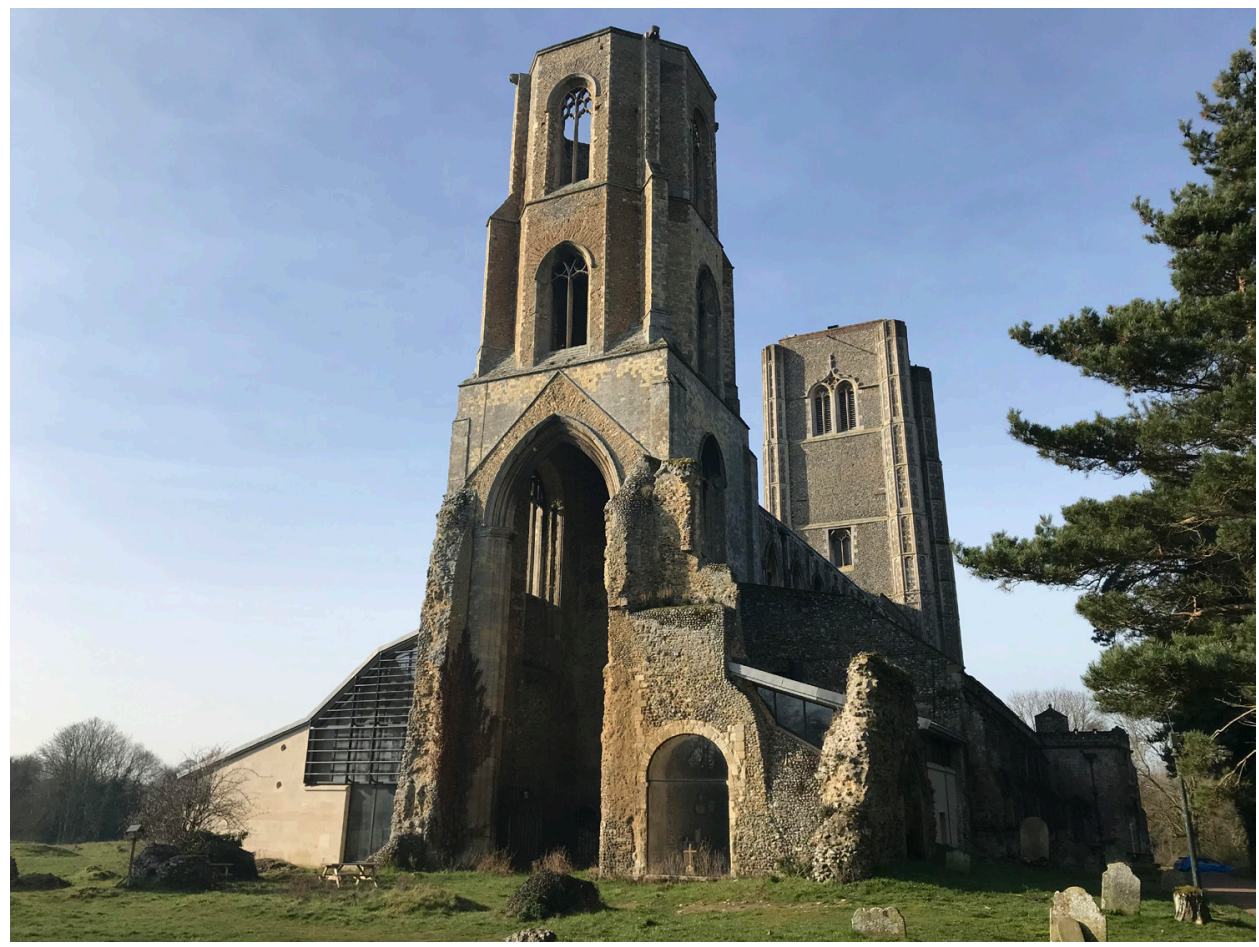

Fig. 1 Wymondham Abbey, Norfolk: external view from north east (2019), photo by author

Significant change is nevertheless possible, as the recent alterations Wymondham Abbey in Norfolk demonstrate (Fig. 1). This large church is the surviving fragment of what, prior to the dissolution of the monasteries, was a much bigger twelfth-century Benedictine priory complex ${ }^{16}$. As well as the church being listed grade $\mathrm{I}^{17}$, its ruined east tower and adjacent standing remains are scheduled ancient monuments, and the interior boasts a remarkable gilded reredos by the renowned twentieth-century architect Sir Ninian Comper. The recent project has provided meeting rooms and ancillary facilities, opened the church up to visitors and created an education and interpretation centre; this involved the removal of some internal accretions and the construction of two extensions in strikingly contemporary architectural language ${ }^{18}$. The

16 Cattermole P. (Ed.), Wymondham Abbey: A history of the monastery and parish church, Wymondham: Wymondham Abbey, 2007.

17 In the UK, lists of buildings under statutory protection are maintained by the national governments; in England and Wales the three levels of protection are grade I (highest), grade II* and grade II (lowest), for buildings of 'exceptional', 'more than special', and 'special' interest respectively.

18 The scheme was designed by the Cambridge architects Freeland Rees Roberts. 


\section{Nigel Walter}

focus of concern from some heritage groups was the southern extension, which enlarged the south aisle eastwards to flank the east tower (to the left in Fig. 1), and projected southwards beyond the line of the south wall. Stakeholder consultations failed to resolve all their concerns, but permission was nevertheless given for the works, which were completed in late 2015 (Fig. 2).

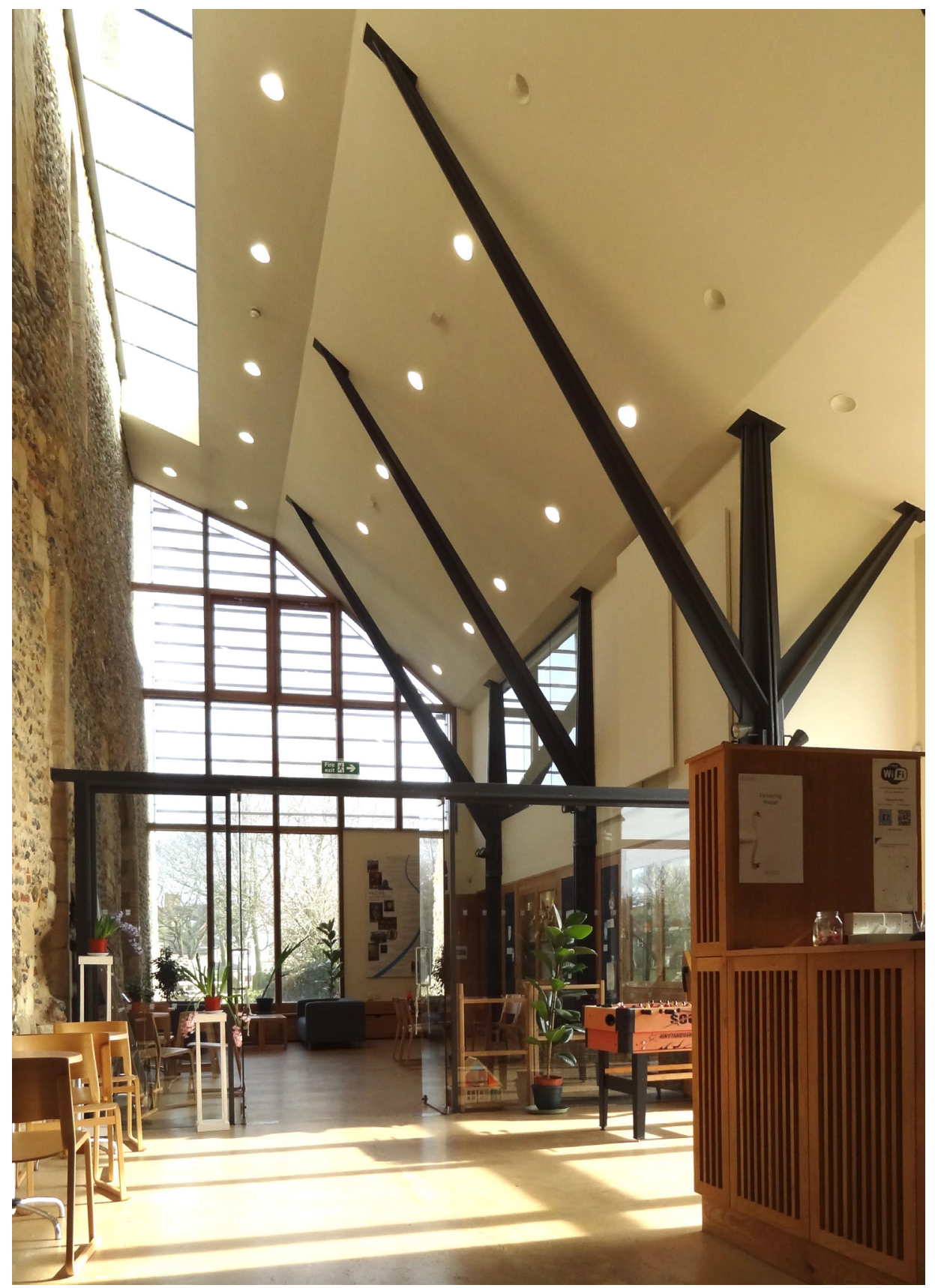

Fig. 2 Wymondham Abbey, Norfolk: view of south extension interpretation/meeting space, looking east (2019), photo by author 
Contrary to what some professionals may believe, church communities such as Wymondham typically care deeply about their buildings; their openness to change, which for some manifests carelessness, may instead demonstrate an alternative and richer understanding of history. There is growing acknowledgement that church buildings are often complex hybrids that have changed multiple times through their history, and indeed that many have only survived because they have changed in step with the community's needs; in this sense, change is part of their nature. In their willingness to countenance change, church communities are able to provide some account of how heritage is actually produced, and may understand better than the professionals that their historic building is capable of being enhanced. They are able to do this by bringing their buildings from the distant past into meaningful (historical) dialogue with the present through the vehicle of tradition; a possible theoretical basis for this is sketched out in the following section.

\section{The narrative approach}

Many historic buildings, like Wymondham Abbey, have developed over time, giving them a multi-faceted character. They typically consist of work of multiple different ages and by different hands, some recognized architects, others anonymous but perhaps no less important. Architectural history struggles with such hybrids, tending to force them into stylistic categories and, where possible, to follow a 'Great Men' approach to their history. By contrast, the approach proposed here employs the metaphor of the historic buildings as an unfinished narrative that is:

- intergenerational - seeing the past in dialogue with the present;

- communal - created by and in turn creating a coherent community across time; and

- ongoing - accepting that those who come after us will have their own chapters to add.

Following the logic of this metaphor, each generation has the opportunity (perhaps even the responsibility) to write a chapter in that ongoing narrative, but in such a way that the narrative as a whole retains its coherence. Of these three elements, the second - the communal - is addressed by the practices of living heritage, including its focus on the core community and traditional craft skills; it also has obvious common ground with social value and intangible heritage theory.

However, it is the first element - the intergenerational - that raises the question of tradition. As noted above, at the heart of conservation lies the paradoxical ambition of attempting to care for the products of tradition using only the intellectual resources of modernity. Since Edmund Burke ${ }^{19}$, writing in the immediate aftermath of the French Revolution, modernity has understood tradition to be intrinsic to political conservatism. But for the philosopher Alasdair MacIntyre ${ }^{20}$, tradition has a quite different and more contemporary relevance, and is bound up with narrative and practices: he sees the life of a person, and by extension a community,

19 Burke E., Reflections on the Revolution in France, Stanford, CA: Stanford University Press, 2001 (Original work published 1790).

20 MacIntyre A. C., After virtue: A study in moral theory (3rd ed.). London: Duckworth, 1985. 


\section{Nigel Walter}

as a narrative that must be read against a social context made up of sets of practices which define the good, and those practices sustain a tradition from which are drawn the standards of rational debate. MacIntyre's argument is that we cannot help but think within a tradition, whether we acknowledge it or not; tradition, properly understood, is dialogical in nature, an extended, intergenerational argument over what constitutes the good. The principal mode of learning what it means to be skilful in any human endeavour is through apprenticeship to a 'craft' (the Greek techne), whether that be stone carving, or parenting, or indeed conservation. Being both dynamic and generative, and because it draws on the resources of premodernity, a well-functioning tradition allows a craft such as conservation to engage positively with the needs of living buildings and their communities, including their ongoing change.

The extent to which we can engage with the past, and the terms of that engagement, is the central concern of hermeneutics, the branch of knowledge concerned with the interpretation of 'texts', of whatever sort. For Hans-Georg Gadamer, who followed his teacher Martin Heidegger in expanding the scope of hermeneutics to all forms of human understanding, it is tradition that enables us to engage with the past, and is thus essential to all understanding. Where a romantic hermeneutic naively believes it is able to access the mind of a historic figure - nineteenth-century conjectural restoration being one obvious example - for Gadamer, understanding involves what he terms a 'fusion of horizons' between present and past:

In a tradition this process of fusion is continually going on, for there old and new are always combining into something of living value, without either being explicitly foregrounded from the other ${ }^{21}$.

Conservation has consistently opposed the destructive effects of modernity's foregrounding of the new from the old, and rightly so. However, until now it has done this simply by inverting their priority, explicitly foregrounding the old from the new. The (unacknowledged) result is to cut the old off from that fusion of horizons which, on Gadamer's understanding, is indispensable to the ongoing health both of the tradition as a whole, and in a conservation context of the object/ building in question within that tradition. Tradition can indeed be said to be 'conservative', not politically but by enabling a society to 'conserve' its central cultural questions, maintaining them in vibrant good health from one generation to the next. Tradition is thus more radical (a return to the root) than conservative in this sense.

The third element identified above - that the narrative of a historic building is ongoing - relates to our understanding of temporality. Paul Ricoeur explored the relation of temporality and narrative, noting their 'structural reciprocity ${ }^{22}$, expanding his study in the three volume Time and Narrative ${ }^{23}$. Subsequently, narrative theory has been widely applied across the humanities; some have resisted this, often out of concern that narrative is misused and psychologically

${ }^{21}$ Gadamer H. G., Truth and method (2nd, rev. ed.; J. Weinsheimer \& D. G. Marshall, Trans.). London: Sheed and Ward, 1989 (Original work published 1960).

22 Ricoeur P., Narrative time, Critical Inquiry, 7(1), 1980, p. 169, https://doi.org/10.2307/1343181.

${ }^{23}$ Ricoeur P., Time and narrative, Vols 1-3 (K. McLaughlin \& D. Pellauer, Trans.), Chicago, IL and London: University of Chicago Press, 1984. 
damaging, particularly when applied as some form of template for deriving individual identity. Peter Lamarque, a philosopher of aesthetics, is one such narrative sceptic who refers to the essential 'opacity of narrative'24 to suggest that, rather than narrative somehow allowing access to a different world, it reveals nothing more than the specific story told. Lamarque and I have debated our differences in a jointly authored paper on the application of narrative theory to historic buildings $s^{25}$. It may well be that the claims of narrative are at times overstated, and that there is danger in expecting it to furnish definitive answers to questions of identity. However, the relevance of narrative is in providing a means of keeping one's identity (or, in a conservation context, the identity of a historic building) in play, that is, still capable of change while preserving the continuity of past, present and future.

In commenting on Ricoeur's Time and Narrative, William Dowling identifies

the double temporality of narrative structure: a telos that carries characters forward in a state of imperfect knowledge about the consequences of their actions, with a narrator who, gazing backward on events from a fixed or totum simul perspective, has arrived at certain conclusions about their meaning or significance $e^{26}$.

The implication of this double temporality is that the experience from within the narrative is contingent, and that it is only the narrator, standing at the end of the story looking back, who can with confidence assign conclusions about the meaning and significance of the events retold; there is an obvious parallel here with Søren Kierkegaard's observation that life can only be understood backwards, but has to be lived forwards. What narrative offers, therefore, is an orientation as much to the future as to the past - in marked contrast to the aesthetic-historical orientation still prevalent within conservation - and an account of the relation of whole to part, which Ricoeur, following Louis Mink, refers to as a 'grasping together ${ }^{27}$.

\section{Implications}

Implicit in the proposed narrative approach is the claim that a building is meaningful primarily for what it represents as a cultural whole, and only secondarily for its parts, however interesting they may be. The current values-based methodology works in the opposite direction, from part to whole, with significance understood as merely the sum of the separate values identified, and with no explanation of how the individual parts form that whole. Similarly, heritage professionals - particularly those concerned with a specific historic period - tend to engage with a building on the basis of those parts that interest them, with the hybrid historical whole seen as of secondary importance or neglected altogether. In the absence of an integrating framework, a values-based

\footnotetext{
${ }^{24}$ Lamarque P., The opacity of narrative, London: Rowman \& Littlefield International, 2014, http://doi. org/10.33134/eeja.181.

${ }^{25}$ Lamarque P., Walter N., The application of narrative to the conservation of historic buildings, Estetika: The Central European Journal of Aesthetics, LVI/XII(1), 2019, pp. 5-27.

${ }^{26}$ Dowling W. C., Ricoeur on time and narrative: An introduction to Temps et récit, Notre Dame, IN: University of Notre Dame Press. 2011, p. 88.

27 Ricoeur P., Narrative time, Critical Inquiry, 7(1), 1980, p. 178, https://doi.org/10.2307/1343181.
} 
methodology will inevitably struggle to provide a historically literate account of the shifting importance of a complex historic building.

Perhaps the key distinction of the proposed narrative approach is that, rather than relying on the apparatus of modernity, it works with the grain of tradition, traditionally understood. As discussed above, tradition on the non-modern understanding is more dynamic than static, as much concerned with the generation of new meanings as the preservation of old ones. It is essential, therefore, that any proposed framework for dealing with the objects of tradition includes a future dimension, as does narrative. Part of knowing what conservation action we should take in the present moment involves an acknowledgement that, whatever the 'chapter' we end up writing in this generation, future generations will wish to write their own; this openness is an inevitable aspect of what it means to be a living building, and is to be welcomed. Ours will not be the last word; therefore, if an intergenerational narrative is to be comprehensive and coherent, the authors of each 'chapter' have a responsibility to leave 'plot lines' open for those who follow. This requires a projection forward to imagine what a future generation of that community might perhaps ask of its building, to ensure where possible that the work currently undertaken does not prohibit that future work.

To treat buildings as ongoing narratives is to allow for continuing cultural production; Stewart Brand, discussing old buildings more generally, touches on the same central metaphor: 'The building already has a story; all you have to do is add the interesting next chapter ${ }^{28}$. Historic buildings have typically already changed multiple times, and that change is an essential aspect of their character; it is unsustainable, therefore, to conflate change with harm, as an art-historically oriented practice too readily does. But if the current 'chapter' is to represent a coherent addition to what in most cases is already a well-developed story, then a narrative approach demands that we understand the plot to date as well as we possibly can. What a narrative approach emphatically does not do, therefore, is to excuse us from a thorough engagement with the past. The narrative approach goes beyond knowledge of the past to an active engagement with the tradition(s) that formed the narrative to date. That engagement is of primary importance in buildings that remain in use for the purpose for which they were built, but applies also for those for which an adaptive reuse has been found.

A further implication of the proposed narrative approach is the rebalancing of the relationship between the core community and the many experts they encounter. Conservation remains overwhelmingly dependent on the expertise of 'the professionals' with a profound unease at the prospect of relinquishing influence to 'the amateurs', including those communities who bear responsibility for the upkeep of many historic buildings. And yet by remaining focused on the interests of experts, conservation practice makes itself an increasing oddity in a climate of greater public participation. The core community is (or at least should be) expert in its locality; the community needs to own that expertise, and the process should treat that expertise with the respect it deserves. The narrative approach acknowledges that these tensions are not new - they have been present from the outset - but takes the optimistic view that this rebalancing offers

${ }_{28}$ Brand S., How buildings learn: What happens after they're built, New York and London: Viking, 1994, p. 105. 
conservation an opportunity to address a number of hitherto unresolved issues. Undoubtedly we still need expertise, but on this model the expert relinquishes a degree of control and becomes the enabler and interpreter of the community's narrative. This would allow conservation to move from a short-sighted defence against change to the nurturing of the fourfold continuity at the heart of living heritage - continuity of use, community, culture, and care ${ }^{29}$.

\section{Conclusion}

The future of conservation as a whole rests on arriving at a more satisfactory relation between conservation's laudable aims and its theoretical grounding. Values-based conservation has significant limitations, particularly when addressing living buildings that combine complex histories with the pressures of ongoing use, because it confines communal/social value to the present generation. It is also open to abuse by professionals who may understand their role as protecting built heritage from its users and the wider public, seen as lacking the necessary expertise to act responsibly. Acknowledging these limitations and the intergenerational character of living buildings is the necessary first step to developing a more successful theoretical framework for conservation in its next phase of development.

Engaging with living buildings invites us to locate heritage at the nexus of people and buildings; this is what we as conservation professionals are tasked with conserving. This paper argues that the narrative approach offers great promise as the foundation of an alternative methodology, transforming buildings from merely being a backdrop to human action to themselves being characters in the dramatic production that is culture. Recognizing that living buildings remain sites of ongoing cultural production will enable conservation to take its rightful place in a much bigger cultural context of communal and societal well-being. This approach has application not only to living religious heritage, but also more widely to conservation as a whole ${ }^{30}$.

\section{Acknowledgements}

The doctoral research on which this article is based was funded by the UK's Arts and Humanities Research Council through the White Rose College of Arts and Humanities.

${ }_{29}$ Poulios I., The past in the present: A living heritage approach-Meteora, Greece, London: Ubiquity Press, 2014; Wijesuriya G., Annexe 1: Living heritage: A summary, 2015, http://www.iccrom.org/wp-content/uploads/ PCA_Annexe-1.pdf.

${ }^{30}$ A fuller treatment of this proposed theoretical framework can be found in my Narrative theory in conservation: Change and living buildings, Abingdon and New York: Routledge, 2020. 


\section{Bibliography}

Araoz G. F., Preserving heritage places under a new paradigm, Journal of Cultural Heritage Management and Sustainable Development, 1(1), 2011, pp. 55-60, https://doi.org/DOI 10.1108/20441261111129933.

Australia ICOMOS, The Burra Charter: The Australia ICOMOS charter for places of cultural significance, 2013, Burwood, Australia: Australia ICOMOS, https://australia.icomos.org/wpcontent/uploads/The-Burra-Charter-2013-Adopted-31.10.2013.pdf.

Brand S., How buildings learn: What happens after they're built, New York and London: Viking, 1994.

Burke E., Reflections on the Revolution in France, Stanford, CA: Stanford University Press, 2001 (Original work published 1790).

Cattermole P. (Ed.), Wymondham Abbey: A history of the monastery and parish church, Wymondham: Wymondham Abbey, 2007.

de Man P., Literary history and literary modernity, Daedalus, 99(2), 1970, pp. 384-404.

Dowling W. C., Ricoeur on time and narrative: An introduction to Temps et récit, Notre Dame, IN: University of Notre Dame Press, 2011.

Gadamer H. G., Truth and method (2nd, rev. ed.; J. Weinsheimer \& D. G. Marshall, Trans.), London: Sheed and Ward, 1989 (Original work published 1960).

Historic England, Conservation principles: Policies and guidance for the sustainable management of the historic environment, London: English Heritage, 2008.

Lagerqvist B., Holmberg I. M., Wetterberg O., Integrated Conservation of Built Environments: Swedish Reflections from Three Decades of Program Development, [in:] B. L. Stiefel, J. C. Wells (Eds.), Preservation education: Sharing best practices and finding common ground (pp. 114-130), University Press of New England, 2014.

Lamarque P., The opacity of narrative, London: Rowman \& Littlefield International, 2014, http:// doi.org/10.33134/eeja.181.

Lamarque P., Walter N., The application of narrative to the conservation of historic buildings, Estetika: The Central European Journal of Aesthetics, LVI/XII(1), 2019, pp. 5-27.

Latour B., We have never been modern (C. Porter, Trans.), Cambridge, MA: Harvard University Press, 1993.

Lipp W., Štulc J., Szmygin B., Giometti S. (Eds.), Conservation turn - return to conservation: Tolerance for change, limits of change, Firenze: Edizioni Polistampa, 2012.

MacIntyre A. C., After virtue: A study in moral theory (3rd ed.), London: Duckworth, 1985.

Petzet M., International principles of preservation, Berlin: Hendrik Bäßler Verlag, 2009.

Poulios I., The past in the present: A living heritage approach-Meteora, Greece, London: Ubiquity Press, 2014. 
RicoeurP.,Narrativetime, Critical Inquiry,7(1), 1980,pp.169-190, https://doi.org/10.2307/1343181. Ricoeur P., Time and narrative, Vols 1-3 (K. McLaughlin \& D. Pellauer, Trans.), Chicago, IL and London: University of Chicago Press, 1984.

Strong R., A little history of the English country church, London: Jonathan Cape, 2007.

Walter N., Everyone loves a good story: Narrative, tradition and public participation in conservation, [in:] G. Chitty (Ed.), Heritage, conservation and communities: Engagement, participation and capacity building (pp. 50-64), Abingdon and New York: Routledge, 2017.

Walter N., Narrative theory in conservation: Change and living buildings, Abingdon and New York: Routledge, 2020.

Wijesuriya G., Annexe 1: Living heritage: A summary, http://www.iccrom.org/wp-content/ uploads/PCA_Annexe-1.pdf.

Wijesuriya G., Thompson J., Court S., People-centred approaches: Engaging communities and developing capacities for managing heritage, [in:] G. Chitty (Ed.), Heritage, conservation and community: Engagement, participation and capacity building (pp. 34-49), Abingdon and New York: Routledge, 2017. 